\title{
IMPLIKASI PEMEKARAN DAERAH KABUPATEN PESAWARAN PROVINSI LAMPUNG PASCA REFORMASI
}

\author{
Lukman Santoso \\ Institut Agama Islam Negeri Ponorogo | Jl. Pramuka I 56 Ponorogo \\ cak_luk2005@yahoo.co.id
}

\begin{abstract}
This article discusses implication of regional expansion of with the creation of Pesawaran Regency, the Province of Lampung, which was legally created based on the Law No. 33/2007 and officially promulgated on $2^{\text {nd }}$ of November 2007. Before becoming a separate regency, Pesawaran was part of South Lampung Regency. There are both positive and negative implications of this expansion. Among positive implications are more effective control, available positions in bureaucracy for locals, better service delivery, fiscal distribution to newly created regency for development and infrastructures. Whereas negative implications include dispute in the site of regency office, shortage in budget allocation, infrastructure limitation, worsening public services and deteriorating relationship among key regional executives.
\end{abstract}

Keywords: Implication, regional expansion, Pesawaran Regency.

Abstrak: Artikel ini mengkaji tentang implikasi pemekaran daerah Kabupaten Pesawaran Provinsi Lampung pasca reformasi. Terbentuknya Kabupaten Pesawaran berdasarkan undang-undang nomor 33 tahun 2007 yang memekarkan diri dari Kabupaten Lampung Selatan, dan diresmikan pada 2 November 2007. Terdapat implikasi positif dan negatif yang timbul dari pemekaran kabupaten Pesawaran Provinsi Lampung. Di antara implikasi positifnya adalah rentang kendali pemerintahan semakin dekat, terbukanya jabatan-jabatan (peluang kerja) baru untuk sebagian kecil masyarakat asli dan sekitar, terutama dalam sektor pemerintahan kabupaten, akses pelayanan publik semakin dekat, dan adanya distribusi fiskal ke daerah otonom baru sebagai upaya pembangunan dan penunjang struktur dan infrastruktur baru. Adapun implikasi negatifnya adalah terjadinya silang sengkarut lokasi kantor pemerintah kabupaten, keterbatasan anggaran sehingga terbengkalainya pemilukada perdana, keterbatasan infrastruktur, pelayanan publik yang 
semakin buruk, dan hubungan kerja yang kurang harmonis antar pimpinan dan pejabat daerah.

Kata Kunci: Implikasi, pemekaran daerah, kabupaten Pesawaran.

\section{Pendahuluan}

Sejak bergulirnya era reformasi 1998, bangsa Indonesia menaruh harapan besar terhadap perubahan-perubahan sistem bernegara. Dalam konteks sistem ketatanegaraan Indonesia, euforia reformasi juga ditandai dengan gelombang otonomi daerah secara besar-besaran. Lahirnya Undang-Undang Pemerintahan Daerah pada kondisi tersebut merupakan salah satu upaya pemerintah "mendinginkan" euforia reformasi dan di lain pihak untuk menjaga keutuhan NKRI. Maka tidak salah jika "nada" Undang-Undang Nomor 22 Tahun 1999 tentang Pemerintahan Daerah memberikan kebebasan yang nyata dan seluas-luasnya bagi daerah untuk menyelenggarakan pemerintahannya sendiri (otonomi) demi kesejahteraan daerah. Prinsip kebebasan, demokrasi, dan partisipasi publik juga sangat menonjol dalam produk hukum tersebut. ${ }^{1}$

Era otonomi daerah juga menjadi penanda bergesernya paradigma sentralisasi yang dianut Orde Baru, menjadi paradigma desentralisasi yang termuat dalam Undang-Undang Nomor 22 Tahun 1999 jo Undang-Undang Nomor 32 Tahun 2004 tentang Pemerintahan Daerah. Fenomena pemekaran daerah atau pembentukan daerah otonom baru (DOB), kemudian menjadi konsekuensi logis dari penerapan kebijakan desentralisasi politik. Dalam konteks politik pasca reformasi, desentralisasi memang lebih dimaknai sebagai kebebasan daerah untuk melakukan pemekaran daerah atau pembentukan daerah otonom baru, baik provinsi, kabupaten/kota, kecamatan maupun desa/kelurahan.

Dalam konteks negara hukum modern (welfare staat), setiap kebijakan pemerintah, termasuk pemekaran daerah harus berimplikasi pada kepentingan umum, yakni memberikan

I Tim Percik, Proses dan Implikasi Sosial-Politik Pemekaran; Studi Kasus di Sambas dan Buton, Summary Paper, (Salatiga: Yayasan Percik, 2007), 5. 
kontribusi positif bagi peningkatan kualitas pelayanan publik yang merata dan terjangkau bagi semua kelompok masyarakat. Ketentuan tersebut sebenarnya secara yuridis telah termuat dalam Undang-Undang Nomor 32 Tahun 2004 yang secara teknis diatur dalam PP Nomor 78 Tahun 2007 sebagai acuan mewujudkan tujuan pemekaran daerah, yakni meningkatkan kesejahteraan rakyat, pelayanan yang lebih baik, peningkatan kehidupan demokratis, pertumbuhan ekonomi yang lebih cepat, meningkatnya keamanan dan ketertiban, relasi yang harmonis antar-daerah, serta memperpendek rentang kendali pemerintahan.

Di balik tujuan ideal itu ternyata terselip kepentingan politik dan kekuasaan yang justru menafikan tujuan pemekaran daerah secara keseluruhan. Telaah atas proses pemekaran daerah juga harus menilik secara cermat pada konteks lokasi, waktu peristiwa, serta konstelasi politik saat terjadinya pemekaran, karena tidak dapat dinafikan bahwa pengaruh politik atas hukum sangat kuat. Hukum dan politik hakikatnya saling mempengaruhi, sehingga dapat dipahami ketika pemekaran daerah hanya merupakan rekayasa elite politik, baik lokal maupun pusat, dengan berbagai kepentingan yang diusungnya, tanpa memperhatikan aspek viability (rasionalitas dan urgensitas), maupun feasibility (kelayakan). ${ }^{2}$

Menguatnya fenomena pemekaran daerah di era reformasi juga merupakan potret lemahnya pemerintahan pusat. Lemahnya pemerintahan pusat dipandang dari kepentingan daerah adalah peluang untuk mengajukan tuntutan (aspirasi) atau melakukan 'resistensi' terhadap negara. Karena pemerintah pusat lemah, maka negara lemah pula dalam menghadapi tekanan-tekanan dari daerah, elite-elite lokal serta mobs (massa bergerak) di daerah. Mobokrasi inilah yang tampaknya dikhawatirkan pemerintah pusat yang lemah itu karena berdampak buruk pada stabilitas dan pembangunan citra yang sedang diupayakan. Kemudian pusat

2 Cornelis Lay dan Purwo Santoso, Perjuangan Menuju Puncak; Kajian Akademik Pembentukan Kabupaten Puncak Jaya Papua, (Yogyakarta: Kerjasama PLOD UGM dan Pemerintah Papua, 2006). 
yang tidak berdaya melakukan politik akomodasi atas tuntutantuntutan daerah, khususnya tuntutan pemekaran. ${ }^{3}$

Jika dibandingkan pengaturan pemekaran daerah pada era Orde Baru yang merujuk Undang-Undang Nomor 5 Tahun 1974, kebijakan pemekaran daerah pasca ditetapkannya Undang-Undang Nomor 22 Tahun 1999 mempunyai perbedaan yang signifikan. Kebijakan pemekaran daerah pada Orde Baru, memang bersifat elitis dan memiliki karakter sentralistis, yang perencanaan dan implementasi pemekaran lebih merupakan inisiatif pemerintah pusat (top-down) daripada partisipasi dari bawah (buttom-up). Pemekaran daerah pada periode ini seringkali menjadi proses yang tertutup dan menjadi arena terbatas di kalangan pemerintah pusat. ${ }^{4}$

Dalam Undang-Undang Nomor 32 Tahun 2004 tentang Pemerintahan Daerah yang secara teknis diatur dalam PP Nomor 78 Tahun 2007 tentang Tata Cara Pembentukan, Penghapusan, dan Penggabungan Daerah ${ }^{5}$ justru lebih menekankan pada prosesproses politik. Ruang bagi daerah untuk mengusulkan pembentukan DOB dibuka lebar. Dengan kebijakan yang demikian ini, pemekaran daerah lebih didominasi oleh proses politik daripada proses teknokratis-administratif. Pemekaran daerah kemudian seolah menjadi pilihan utama untuk mewujudkan aspirasi daerah. Padahal dalam konteks penataan daerah, pemekaran justru bermakna pemekaran dan penggabungan daerah. Produk hukum ini berdampak pada maraknya pemekaran daerah yang tidak terbendung di seluruh Indonesia, terutama di

\footnotetext{
${ }^{3}$ Tri Ratnawati, Pemekaran Daerah; Politik Lokal dan Beberapa Isu Terseleksi, (Yogyakarta: Pustaka Pelajar, 2009), 33.

4 Soetandyo Wignjosoebroto, "Satu Abad Desentralisasi di Indonesia", dalam Majalah Prisma No 3, Vol 29/ Juli 2010, 68.

${ }^{5}$ Revisi terhadap UU No. 22 Tahun 1999 dengan UU No. 32 Tahun 2004 dan PP 129 Tahun 2000 dengan PP No 78 Tahun 2007 yang merupakan regulasi teknikalitas pemekaran daerah, sejatinya bertujuan untuk memperketat syarat administratif, teknis dan fisik kewilayahan, namun dalam praktiknya masih terdapat banyak kelemahan dalam Undang-Undang dan peraturan pemerintah tersebut, kondisi tidak lain karena tidak ada itikad baik dari elite politik.
} 
luar Jawa, yang mencapai hampir 95 persen. ${ }^{6}$ Untuk pulau Sumatra, termasuk di Provinsi Lampung, angka kenaikannya mencapai 150\% dari tahun 1999-2009. Derasnya gelombang pemekaran ini kemudian juga berdampak pada timbulnya berbagai problem di daerah yang baru dimekarkan tersebut. ${ }^{7}$

Pemekaran daerah di Provinsi Lampung, selain berlangsung cukup pesat dalam dasawarsa terakhir juga berimplikasi pada banyak aspek administratif dan kehidupan sosial-politik. Sejak reformasi, di Provinsi Lampung telah terbentuk 7 (tujuh) daerah otonom baru, yakni: Kabupaten Lampung Timur yang mekar dari Kabupaten Lampung Tengah; Kota Metro yang mekar dari Kabupaten Lampung Tengah; Kabupaten Way Kanan yang mekar dari Kabupaten Lampung Utara; Kabupaten Pesawaran yang mekar dari Kabupaten Lampung Selatan; Kota Pringsewu yang mekar dari Kabupaten Tanggamus; Kabupaten Mesuji yang mekar dari

\footnotetext{
${ }^{6}$ Murtir Jeddawi, Pro-Kontra Pemekaran Wilayah; Analisis Emperis, (Yogyakarta: Total Media, 2009), I I I. Sebelum reformasi, jumlah daerah otonom di Indonesia sebanyak 249 kabupaten, 65 kota, dan 27 provinsi. Namun, pasca reformasi hingga Desember 2009 telah terbentuk 205 daerah otonom baru yang terdiri dari tujuh (7) provinsi, 164 kabupaten dan 34 kota. Dengan demikian total jumlahnya mencapai 524 daerah otonom yang terdiri dari 33 provinsi, 398 kabupaten, dan 93 kota, 5 kota administratif dan I kabupaten administratif. Terlebih Kementerian Dalam Negeri di tahun 2010 tengah memproses I8I usulan. Artinya, jika usulan tersebut kemungkinan diloloskan, Indonesia akan mempunyai sekitar 700 daerah otonom. Lihat Sudi Fahmi, Hukum Otonomi Daerah, (Yogyakarta: Kreasi Total Media, 20 I0), 4. Lihat pula Rekapitulasi Daerah Otonom Baru (DOB) 1999-2009 Ditjen Otonomi Daerah Kemendagri, I. Lihat pula Gamawan Fauzi, "Paradigma Kewenangan Daerah yang Efektif dan Efisien", dalam Majalah Prisma, Volume 29/No 3/Tahun 20 I 0, 79. Serta lihat Antonius Tarigan, "Dampak Pemekaran Wilayah", dalam Majalah Perencanaan Pembangunan, Edisi I, Tahun XVI, $2010,22$.

7 Jumlah daerah pemekaran yang relatif sukses tidak sebanding dengan sekitar $80 \%$ daerah pemekaran yang bermasalah karena dugaan kasus-kasus korupsi DAU, rekrutmen pegawai daerah pemekaran yang tidak fair (berbau kronisme, kekeluargaan dan sukuisme (nepotisme), serta politik uang, munculnya bisnis-bisnis dadakan pejabat daerah/politisi lokal atau keluarganya, konflik tapal batas wilayah (yang tidak jarang tumpang tindih dengan kepentingan partai tertentu), konflik asset daerah, konflik lokasi ibukota baru, konflik antar elit lokal, konflik horizontal, dan beberapa persoalan lain. Lihat Laurensius Daniel, "Problem Pemekaran Daerah dan Prospek Otonomi Daerah", dalam www.equator-news.com, akses I 5 Januari 20 I6. Demikian pula hasil survey Kompas pada 2008 tentang pemekaran daerah, yang menyimpulkan bahwa sekitar 60,5 persen responden membenarkan kerugian dari proses pemekaran ini. Bahkan sejumlah masyarakat di daerah pemekaran baru menilai keadaan lebih buruk terkait perekonomian, pengelolaan sumber daya alam, stabilitas politik, penegakan hukum, pertanahan, administrasi usaha, kesehatan masyarakat, pendidikan, peribatan, dan kamtibmas. Lihat Kompas, Edisi I I Februari 2008, 5.
} 
Kabupaten Tulang Bawang; dan Kabupaten Tulang Bawang Barat yang mekar dari Kabupaten Tulang Bawang.

Problem yang hadir dalam proses pemekaran di Lampung juga terkait tujuan awal pemekaran yang kurang berhasil, yakni mendekatkan akses masyarakat terhadap pelayanan publik yang baik, meningkatkan partisipasi masyarakat, dan mendorong pertumbuhan ekonomi daerah setempat (kesejahteraan). Justru daerah-daerah otonom baru kerap menimbulkan masalah baru, mulai dari tumpang tindih wewenang, proyek sepihak dengan pengusaha lokal, hingga menjadi ladang baru kolusi dan korupsi. ${ }^{8}$ Realitas ini terjadi karena dalam konteks otonomi daerah, belum diatur batas-batas kewenangan di antara setiap pemerintah secara jelas. Model kelembagaan daerah otonom baru juga belum disesuaikan dengan karakteristik daerah. Semua daerah baru dipandang memiliki kapasitas sama sehingga struktur kelembagaannya diseragamkan. ${ }^{9}$

Terbentuknya Kabupaten Pesawaran berdasarkan UndangUndang Nomor 33 Tahun 2007, diundangkan pada tanggal 10 Agustus 2007 dan diresmikan menjadi kabupaten pada tanggal 2 November 2007. Sejak saat itu, Pesawaran resmi menjadi Kabupaten ke-11 di Provinsi Lampung yang wilayahnya meliputi Kecamatan Gedongtataan, Negeri Katon, Tegineneng, Waylima, Kedondong, Padang Cermin, dan Kecamatan Punduh Pedada, dengan Ibukota kabupaten di Gedongtataan.

Kemudian sebagai tindak lanjut penetapan Undang-Undang Nomor 33 Tahun 2007, Menteri Dalam Negeri menerbitkan Pedoman Pelaksanaan Undang-Undang tentang Pembentukan Kabupaten/Kota melalui Surat Menteri Dalam Negeri Nomor. 135/2051/SJ tanggal 31 Agustus 2007 dan pada tanggal 2 November 2007 Menteri Dalam Negeri atas nama Presiden Republik Indonesia, melaksanakan peresmian pembentukan Kabupaten Pesawaran

\footnotetext{
${ }^{8}$ Ibid.

9 M Fajar Marta dan Yulvianus Harjono, "Otonomi Daerah Lampung (6), Pemekaran Masihkah Perlu?", dalam Kompas, Edisi Selasa, 2 November 2010.
} 
dengan melantik Drs. H. Haris Fadilah, M.M sebagai Pejabat Bupati Pesawaran yang pertama dan dilanjutkan dengan penandatanganan prasasti oleh Menteri Dalam Negeri atas nama Presiden Republik Indonesia. ${ }^{10}$

Dalam konteks pemekaran Kabupaten Pesawaran, harapan ideal pemekaran adalah untuk meningkatkan kesejahteraan masyarakat dan memperpendek rentang kendali pemerintahan. Di satu sisi implementasi, pemekaran ini memang membuahkan hasil yang positif, karena masyarakat dapat dengan mudah menjangkau pusat pemerintahan dan akses pelayanan dibanding sebelumnya. Tetapi di sisi lain, pemekaran yang lahir tanpa didasarkan kondisi objektif Kabupaten Pesawaran berdampak pada timbulnya berbagai persoalan, termasuk persoalan administratif dan sosiopolitik. Misalnya saja ketika awal dibentuk melalui UndangUndang Nomor 33 Tahun 2007, kabupaten ini mengalami persoalan tanah lokasi kantor kabupaten. Padahal secara yuridis ketentuan lokasi kabupaten merupakan bagian dari kajian daerah yang harus ada sejak diusulkan. Selain itu, Pemilukada Pesawaran yang dilaksanakan pada 2010 melewati batas ketentuan yang ditetapkan Undang-Undang Nomor 33 Tahun 2007, yakni 2 tahun lebih lama. ${ }^{11}$

Selain itu, sejak dimekarkan, berbagai kewajiban Kabupaten Lampung Selatan sebagai kabupaten induk dan Provinsi Lampung sebagaimana yang tertuang dalam ketentuan Pasal 15 dan 16 Undang-Undang Nomor 33 Tahun 2007 tidak tepat waktu dan cenderung setengah hati. Termasuk di antaranya penyerahan alokasi dana perimbangan dari kabupaten induk, penyerahan asset, penyerahan personalia, dan beberapa persoalan lain.

\footnotetext{
10 "Sejarah Terbentuknya Kabupaten Pesawaran", dalam http:// pesawarankab.go.id/, akses I5 Januari 2016.

"I Menurut ketentuan Pasal 10 ayat (I) UU No 33 Tahun 2007 tentang Pembentukan Kabupaten Pesawaran dinyatakan bahwa, untuk memimpin penyelenggaraan pemerintahan di Kabupaten Pesawaran dipilih dan disahkan Bupati dan Wakil Bupati, sesuai dengan peraturan perundangundangan, paling lama I (satu) tahun sejak terbentuknya Kabupaten Pesawaran. Lihat juga Taryono, "Dilema Demokrasi dan Otonomi Daerah," dalam Tribun Lampung Edisi 25 Maret 2010.
} 
Artikel ini akan memfokuskan kajian pada pemekaran Kabupaten Pesawaran dengan mengkaji lebih mendalam mengenai Implikasi Pemekaran Daerah Kabupaten Pesawaran Provinsi Lampung Pasca Reformasi di Indonesia.

\section{Konsep Demokrasi Lokal dalam Pemekaran Daerah}

Menurut Deliar Noer, demokrasi sebagai dasar hidup bernegara memberi pengertian bahwa pada tingkat terakhir rakyat memberikan ketentuan dalam masalah-masalah mengenai kehidupannya, termasuk dalam hal menilai kebijaksanaan negara, oleh karena kebijaksanaan tersebut menentukan kehidupan rakyat. ${ }^{12}$

Salah satu perwujudan demokratisasi di tingkat lokal adalah keberadaan konsep desentralisasi pemerintahan sejak era reformasi sebagai anti tesis dari konsep sentralisasi yang diterapkan Orde Baru. Implikasinya, terjadi pergeseran lokus kekuasaan dari pusat ke daerah. Dengan semangat desentralisasi, daerah memiliki kewenangan berotonomi yang semakin luas. ${ }^{13}$ Desentralisasi secara umum dikategorikan ke dalam dua perspektif utama, yakni perspektif desentralisasi politik dan desentralisasi administrasi. Perspektif desentralisasi politik menerjemahkan desentralisasi sebagai devolusi kekuasaan dari pemerintah pusat kepada pemerintah daerah; sedangkan perspektif desentralisasi administrasi diartikan sebagai pendelegasian wewenang administratif dari pemerintah pusat kepada pemerintah daerah. ${ }^{14}$

Jika desentralisasi merupakan arena hubungan antara pemerintah daerah dengan pemerintah pusat yang bertujuan untuk memberikan pengakuan terhadap eksistensi masyarakat lokal, memperkuat identitas lokal, membangkitkan prakarsa dan inisiatif lokal, serta membagi kekuasaan dan kekayaan kepada masyarakat

\footnotetext{
${ }_{12}$ Deliar Noer, Pengantar ke Pemikiran Politik, (Jakarta: CV. Rajawali, I983), 207.

13 Sudi Fahmi, Hukum Otonomi Daerah (Yogyakarta: Total Media, 2010 ), 21.

14 Syarif Hidayat, Refleksi Realitas Otonomi Daerah dan Tantangan ke Depan, (Jakarta: Pustaka Quantum, 2000).
} 
lokal, dan mewujudkan otonomi luas, ${ }^{15}$ maka demokratisasi merupakan upaya untuk menjadikan penyelenggaraan pemerintahan daerah menjadi lebih akuntabel, responsif, diakui oleh rakyat; mendorong peran legislatif daerah berfungsi sebagai badan perwakilan dan intermediary agent; serta memperkuat partisipasi masyarakat daerah dalam proses pemerintahan dan pembangunan daerah. Partisipasi juga menandai keikutsertaan kalangan marjinal yang selama ini disingkirkan dari proses politik dan ekonomi. ${ }^{16}$

Pemerintahan lokal yang demokratis berkaitan erat dengan akuntabilitas, kompetisi, keterlibatan, dan tinggi rendahnya kadar untuk menikmati hak-hak dasar bagi pemilih di daerah. Sehingga pemahaman berdemokrasi tidak hanya sebatas memilih gubernur, bupati atau walikota dan para wakil rakyat dari daerah, tetapi masa depan dan kemakmuran daerah. ${ }^{17}$ Dengan keleluasaan daerah otonom dalam mengatur dan mengurus urusan rumah tangganya, akan memberikan peluang daerah untuk tata kelola kewenangannya dalam suasana pemerintahan demokratis. Artinya tidak saja pelibatan masyarakat dalam proses perencanaan, pelaksanaan dan pengawasan kebijakan publik, akan tetapi kebijakan publik yang dirumuskan mengarah kepada kemajuan daerah yang signifikan, diiringi pelayanan publik yang semakin baik. ${ }^{18}$ Termasuk pelibatan masyarakat dalam penataan daerah dan pemekaran daerah sebagai cermin keberhasilan dari otonomi daerah.

Pelaksanaan pemerintahan daerah merupakan salah satu aspek struktural dari suatu negara sesuai dengan pandangan bahwa negara sebagai sebuah organisasi, jika dilihat dari sudut

15 Tim Lapera, Otonomi Versus Negara; Demokrasi di Bawah Bayang-Bayang Otoriterisme, (Yogyakarta: Lapera Pustaka Utama, 2005), 153.

${ }^{16}$ Sudi Fahmi, Hukum Otonomi..., 22.

Rahmatul Ummah As Saury, "Memperkuat Demokrasi Lokal", dalam http://politik.kompasiana.com/2010/I I/04/memperkuat-demokrasi-lokal/, diakses tanggal I5 Februari 2016.

18 Murtir Jeddawi, Pro-Kontra Pemekaran Wilayah; Analisis Emperis, (Yogyakarta: Total Media, 2009), 7. 
ketatanegaraan. Sebagai sebuah organisasi, pelaksanaan pemerintahan daerah diharapkan dapat memperlancar mekanisme roda kegiatan organisasi. Pendelegasian sebagian wewenang dari seseorang atau instansi suatu organisasi merupakan salah satu asas yang berlaku universal bagi setiap organisasi, yaitu dengan tujuannya agar kebijakan dapat terlaksana dengan efektif, meringankan beban kerja pimpinan, memencarkan peranan pimpinan sehingga terjadi demokratisasi dalam kegiatan organisasi. ${ }^{19}$

Esensi pemerintahan di daerah berkaitan dengan kewenangan yang dimiliki dalam mengurus dan mengatur rumah tangganya. Kewenangan pemerintah daerah berkaitan dengan pembagian kekuasaan dalam penyelenggaraan pemerintahan, yang terpola dalam sistem pemerintahan negara federal dan negara kesatuan. Sistem negara federal terpola dalam tiga struktur tingkatan utama, yaitu pemerintah federal (pusat), pemerintah negara bagian (provinsi), dan pemerintah daerah otonom. Sedangkan sistem negara kesatuan terpola dalam dua struktur tingkatan utama, yaitu pemerintah pusat dan pemerintah daerah (provinsi, kabupaten dan kota). ${ }^{20}$

Tinjauan pemerintahan negara kesatuan terformat dalam dua sendi utama, yaitu sistem pemerintahan yang sifatnya sentralistik atau desentralistik. Kedua sifat ini menciptakan karakter hubungan antara pemerintah pusat dengan pemerintah daerah, yang terkait dengan bentuk, susunan, serta pembagian kekuasaan atau kewenangan yang ada pada negara. Artinya, dari bentuk dan susunan negara dapat dilihat apakah kekuasaan itu dibagi ke daerah-daerah atau kekuasaan itu dipusatkan di pemerintah pusat. Dari sisi pembagian kekuasaan dalam suatu negara, maka bisa

\footnotetext{
19 Mustamin DG. Matutu dkk, Mandat, Delegasi, Attribusi dan Implementasinya di Indonesia, (Yogyakarta: UII Press, 1999), 24-26.

20 Penggambaran nyata penerapan bentuk negara dapat dilihat pada pemerintahan Amerika Serikat untuk bentuk negara federal, dan Indonesia untuk bentuk negara kesatuan. Lihat R. M. A. B. Kusuma, Lahirnya Undang-Undang Dasar 1945, (Jakarta: Pusat Studi Hukum Tata Negara Fakultas Hukum Universitas Indonesia, 2004), 299.
} 
berbentuk sistem sentralisasi atau sistem desentralisasi. Sistem ini secara langsung mempengaruhi hubungan pusat dengan daerah dalam pelaksanaan pemerintahan di daerah. ${ }^{21}$

Pemberian sebagian kewenangan (kekuasaan) kepada daerah berdasarkan hak otonomi (negara kesatuan dengan sistem desentralisasi), tetapi pada tahap akhir, kekuasaan tertinggi tetap di tangan pusat. Jadi, kewenangan yang melekat pada daerah tidaklah berarti bahwa pemerintah daerah itu berdaulat sebab pengawasan dan kekuasaan tertinggi masih tetap terletak di tangan pemerintah pusat. Hubungan pemerintah pusat dengan daerah dalam suatu negara kesatuan yang gedecentraliseerd, pemerintah pusat membentuk daerah-daerah, serta menyerahkan sebagian dari kewenangannya kepada daerah-daerah. ${ }^{22}$

Kewenangan dalam pelaksanaan pemerintahan daerah, meliputi kewenangan membuat perda-perda (zelfwetgeving) dan penyelenggaraan pemerintahan (zelfbestundang-undangr) yang diemban secara demokratis. Pelimpahan atau penyerahan wewenang dari pemerintah pusat kepada daerah-daerah otonom bukanlah karena ditetapkan dalam konstitusinya, melainkan disebabkan oleh hakikat negara kesatuan itu sendiri. Prinsip pada negara kesatuan ialah bahwa yang memegang tampuk kekuasaan tertinggi atas segenap urusan negara adalah pemerintah pusat (central government), tanpa adanya gangguan oleh suatu delegasi atau pelimpahan kekuasaan kepada pemerintah daerah (local government).23 Pengaturan pelaksanaan kekuasaan negara mempunyai dua bentuk, yaitu dipusatkan atau dipencarkan. Jika kekuasaan negara dipusatkan maka terjadi sentralisasi, demikian pula sebaliknya, jika kekuasaan negara dipencarkan maka terjadi desentralisasi. Dalam berbagai perkembangan pemerintahan,

\footnotetext{
${ }^{21}$ Agussalim Andi Gadjong, Pemerintahan Daerah dalam Kajian Politik dan Hukum, (Bogor: Ghalia Indonesia), 62.

22 Ibid., 78.

23 M. Laica Marzuki, "Hukum dan Pembangunan Daerah Otonom", Kertas Kerja PSKMP-LPPM UNHAS Makassar I 8 Nopember 1999, 12.
} 
dijumpai arus balik yang kuat ke arah sentralistik, yang disebabkan faktor-faktor tertentu. ${ }^{24}$

Talizuhulu Ndraha, menyebutkan bahwa terdapat lima posisi daerah, yaitu: 1) sebagai masyarakat hukum; 2) sebagai unit usaha ekonomi; 3) sebagai lingkungan budaya; 4) sebagai suatu lingkungan; dan 5) sebagai sub sistem politik. ${ }^{25}$ Untuk menjalankan fungsi tersebut secara baik, maka daerah harus ditata dengan baik agar kesejahteraan masyarakat tercipta dengan baik melalui pelayanan publik yang lebih baik, kehidupan demokratis yang semakin berkembang, pertumbuhan ekonomi yang semakin cepat, keamanan dan tatanan daerah yang semakin baik serta hubungan yang selaras antar daerah.

Selanjutnya Ndraha menyatakan, dalam iklim demokratis, pembentukan daerah otonom merupakan persoalan hubungan kemanusiaan dengan negara. Dalam berotonom, ketidakmampuan atau melemahnya daerah otonom akibat kecilnya resources haruslah dikelola dengan baik terutama oleh pemerintah sebagai elemen penyelenggara desentralisasi. Tanggung jawab pemerintah harus besar dalam memandirikan daerah serta memajukannya. ${ }^{26}$

\section{Implementasi Pemekaran Daerah}

Karakteristik pemerintahan yang demokratis dengan prinsip otonomi tentu menjadikan kualitas pelayanan publik sebagai tolak ukur keberhasilan pemerintahan di pusat maupun di daerah. Sedangkan dalam konteks desentralisasi, pelayanan publik yang baik hanya dapat dihasilkan dengan penataan pemerintahan yang baik dari tingkat pusat hingga daerah.

Implementasi desentralisasi dalam negara kesatuan, mengandung dua elemen pokok, yaitu pembentukan daerah otonom dan penyerahan kewenangan secara hukum dari

\footnotetext{
24 The Liang Gie, Pertumbuhan Pemerintahan Daerah di Negara Republik Indonesia (I), (Jakarta: Gunung Agung, 1967), 38-39.

${ }^{25}$ Ni'matul Huda, Hukum Pemerintahan Daerah, (Jakarta: Penerbit Nusamedia, 2009), 55

${ }^{26}$ Ajarotni Nasution (ed.), Naskah Akademik tentang Penghapusan dan Penggabungan Daerah, (Jakarta: BPHN, Depkumham, 2008), 34.
} 
pemerintah pusat ke pemerintah daerah untuk mengatur dan mengurus dan atau bagian dari urusan pemerintahan tertentu. Artinya, memberikan hak untuk mengatur dan mengurus kepentingan dan aspirasi masyarakat di daerah menuju percepatan pembangunan dan kesejahteraan, termasuk pembentukan daerah, tetapi tidak dimungkinkan adanya daerah yang bersifat negara. ${ }^{27}$ Pembentukan daerah yang dimaksud dapat berupa penggabungan (consolidation/amalgamation) beberapa daerah atau bagian daerah yang bersandingan atau pemekaran (fragmentation) dari satu daerah menjadi dua daerah atau lebih. ${ }^{28}$

Pemekaran daerah terdiri dari dua bangunan kata, yakni pemekaran dan daerah. 'Pemekaran' dalam Kamus Besar Bahasa Indonesia diartikan sebagai proses, cara, perbuatan menjadikan bertambah besar, luas, banyak, lebar, dan sebagainya. Sedangkan arti 'daerah' sering dipertukarkan dengan arti wilayah, Hal itu terjadi karena masih terbatasnya literatur yang membahas masingmasing kata secara spesifik. Dalam Kamus Politik, ${ }^{29}$ daerah diartikan sebagai lingkungan pemerintahan, wilayah, tempattempat sekeliling atau termasuk dalam lingkungan suatu kota atau wilayah. Sedang dalam kamus politik internasional pemekaran daerah identik dengan istilah redistricting. ${ }^{30}$ Adapun dalam bahasa hukum, pemekaran daerah diartikan sebagai pemecahan daerah provinsi, daerah kabupaten, dan daerah kota menjadi lebih dari satu daerah, berdasarkan kriteria kemampuan ekonomi, potensi daerah, sosial budaya, sosial politik, jumlah penduduk, luas daerah, pertimbangan lain yang memungkinkan terselenggaranya otonomi daerah. $^{31}$ Definisi ini hampir sama dengan definisi pemekaran daerah menurut Pasal 1 PP nomor 78 Tahun 2007 yang mengartikan

\footnotetext{
${ }^{27}$ Agussalim Andi Gadjong, Pemerintahan, 76.

${ }^{28}$ Suahazil Nazara dan Nurkholis, "Evaluasi Pemekaran Wilayah kabupaten/ Kota di Indonesia dalam Era Desentralisasi", dalam Jurnal Ekonomi, Volume 5, No 2, 2006, 135.

${ }^{29}$ B.N. Marbun, Kamus Politik, Edisi Baru, (Jakarta: Pustaka Sinar Harapan, Jakarta, 2007), 105.

30 Henk Schulte Nordholt dan Gerry Van Klinken (ed.), Politik Lokal di Indonesia, (Jakarta: Yayasan Obor Indonesia-KITLV, 2007), 25.

3! Vera Jasini Putri, Kamus Hukum dan Glosarium Otonomi Daerah, (Jakarta: YPBHI, 2003), 106.
} 
pemekaran daerah sebagai pemecahan provinsi atau kabupaten/kota menjadi dua daerah atau lebih.

Pemekaran daerah sebagai aspek dari penataan daerah, menurut Michael A. Trueblood dan Beth Walter Honadle, merupakan bagian dari restrukturisasi pemerintahan daerah yang terdiri dari empat bentuk, yaitu: ${ }^{22}$ (1) Aneksasi (anectation), yaitu memperluas wilayah perbatasan daerahnya dengan memasukkan wilayah yang sebelumnya tidak masuk dalam wilayah yang ditangani. (2) Penggabungan (consolidation/amalgamation), yaitu penggabungan antara dua atau lebih pemerintahan daerah yang berdampingan dan membentuk menjadi satu pemerintahan daerah. (3) Pemekaran (fragmentation), yaitu pemecahan dari satu pemerintahan daerah menjadi dua atau lebih pemerintahan daerah. (4) Pelepasan (detachment), yaitu penataan ulang terhadap perbatasan wilayah dengan melepaskan beberapa bagian wilayah dari wilayah yang dilingkupinya.

Menurut Siswanto Sunarno, pembentukan daerah pada dasarnya dimaksudkan untuk meningkatkan pelayanan publik guna mempercepat terwujudnya kesejahteraan masyarakat di samping sebagai sarana pendidikan politik di tingkat lokal. Pembentukan daerah pemerintahan dapat dilakukan dalam dua tipe atau bentuk, yakni berupa penggabungan beberapa daerah atau pemekaran daerah menjadi dua daerah atau lebih. ${ }^{33}$

Pemekaran daerah juga dapat dipahami sebagai pembagian kewenangan administratif dari satu wilayah menjadi dua atau beberapa wilayah. Pembagian tersebut juga menyangkut luas wilayah maupun jumlah penduduk sehingga lebih mengecil. Pada level provinsi menghasilkan satu pola yakni dari satu provinsi menjadi satu provinsi baru dan satu provinsi induk. Sementara pada level kebupaten terdiri dari beberapa pola yakni, Pertama, dari

\footnotetext{
32 Agung Djojosoekarto, dkk, Grand Strategy Penataan Daerah Tahun 2025, (Jakarta: Kemitraan, 2008), 15.

${ }^{33}$ Siswanto Sunarno, Hukum Pemerintahan Daerah di Indonesia, (Jakarta: Penerbit Sinar Grafika, 2009), 15
} 
satu kebupaten menjadi satu kabupaten baru (Daerah Otonom Baru; DOB) dan kabupaten induk. Kedua, dari satu kabupaten menjadi satu kota baru dan kabupaten induk. Ketiga, dari satu kabupaten menjadi dua kabupaten baru dan satu kabupaten induk. ${ }^{34}$

Pembentukan daerah dapat muncul dalam tiga bentuk, yaitu pemisahan (split-off), perluasan (enlarging) dan penyatuan (amalgamation). Dari ketiga konsep tersebut memiliki tujuan dan pertimbangan serta dampak yang berbeda terhadap proses pembangunan daerah bersangkutan. ${ }^{35}$

Charles Tibout, pertama kali mengkaji pemekaran daerah dengan pendekatan public choice school melalui artikelnya "A Pure Theory of Local Expenditure". Dalam artikel tersebut ia mengemukakan bahwa pemekaran daerah dianalogikan sebagai model ekonomi persaingan sempurna dimana pemerintah daerah memiliki kekuatan untuk mempertahankan tingkat pajak yang rendah, menyediakan pelayanan yang efisien, dan mengijinkan setiap individu masyarakat untuk mengekspresikan preferensinya untuk setiap jenis pelayanan dari berbagai tingkat pemerintah yang berbeda. ${ }^{36}$

Secara yuridis, landasan yang memuat persoalan pemekaran daerah terdapat dalam UUD 1945 pasal 18, yang intinya bahwa "Negara Kesatuan Republik Indonesia dibagi atas daerah provinsi dan daerah provinsi itu dibagi atas kabupaten dan kota, yang tiaptiap provinsi, kabupaten dan kota itu mempunyai pemerintahan daerah yang diatur dengan Undang-Undang. Selain itu, pemerintahan daerah juga berhak menjalankan otonomi seluasluasnya, kecuali urusan pemerintahan yang oleh Undang-Undang ditentukan sebagai urusan pemerintah pusat."

\footnotetext{
${ }^{34}$ Antonius Tarigan, "Dampak Pemekaran Wilayah," dalam Majalah Perencanaan, Edisi 0I/ tahun $\mathrm{XVI} / 2010,15$

${ }^{35}$ Djojosoekarto, dkk, Grand Strategy, 158.

${ }^{36}$ Suahazil Nazara dan Nurkholis, "Evaluasi Pemekaran Wilayah kabupaten/ Kota di Indonesia dalam Era Desentralisasi", dalam Jurnal Ekonomi, Volume 5, No 2, 2006, I 42.
} 
Selanjutnya dalam Undang-Undang Nomor 32 Tahun 2004 sebagai revisi atas Undang-Undang Nomor 22 Tahun 1999 tentang Pemerintahan Daerah, disebutkan memberi peluang pembentukan daerah dalam suatu NKRI, yaitu daerah yang dibentuk berdasarkan pertimbangan kemampuan ekonomi, potensi daerah, sosial budaya, sosial politik, jumlah penduduk, luas daerah dan pertimbangan lain yang memungkinkan terselenggarakannya otonomi daerah. Untuk teknikalitas pembentukan daerah diatur melalui PP 129 Tahun 2000 jo PP nomor 78 tahun 2007.

Sementara itu, tujuan pemekaran daerah pada Pasal 2 PP Nomor 129 Tahun 2000 tentang Persyaratan Pembentukan dan Kriteria Pemekaran, Penghapusan dan Penggabungan Daerah, dinyatakan bahwa tujuan dari pembentukan, pemekaran, penghapusan dan penggabungan daerah adalah untuk meningkatkan pelayanan kepada masyarakat, percepatan pertumbuhan kehidupan demokrasi, percepatan pelaksanaan pembangunan perekonomian daerah, percepatan pengelolaan potensi daerah, peningkatan keamanan dan ketertiban serta peningkatan hubungan yang serasi antara pusat dan daerah.

Menurut Arif Rosman Effendy, ${ }^{37}$ terdapat beberapa alasan mengapa pemekaran daerah menjadi pendekatan yang diminati dalam kaitannya dengan penyelenggaraan pemerintahan daerah, yaitu: Pertama, keinginan untuk menyediakan pelayanan publik yang lebih baik dalam wilayah kewenangan yang terbatas/terukur. Pendekatan pelayanan melalui pemerintahan daerah yang baru diasumsikan akan lebih dapat memberikan pelayanan yang lebih baik dibandingkan dengan pelayanan melalui pemerintahan daerah induk dengan cakupan wilayah pelayanan yang lebih luas. Kedua, mempercepat pertumbuhan ekonomi penduduk setempat melalui perbaikan kerangka pengembangan ekonomi daerah berbasiskan potensi lokal. Dengan dikembangkannya daerah baru yang otonom, maka akan memberikan peluang untuk menggali berbagai potensi

${ }^{37}$ Lukman Santoso, "Problematika Pemekaran Daerah Pasca Reformasi di Indonesia," Supremasi Hukum, Vol. I, No. 2, Desember 20I2, 275. 
ekonomi daerah baru. Ketiga, penyerapan tenaga kerja secara lebih luas di sektor pemerintah dan bagi-bagi kekuasaan dibidang politik dan pemerintahan. Kenyataan politik seperti ini karena berbagai peluang ekonomi baru baik secara formal maupun informal menjadi lebih tersedia sebagai dampak ikutan pemekaran daerah.

Pembentukan daerah harus memperhatikan berbagai faktor, seperti kemampuan ekonomi, potensi daerah, luas wilayah, kependudukan, dan pertimbangan dari aspek sosial politik, sosial budaya, pertahanan keamanan, serta pertimbangan lain yang memungkinkan daerah itu untuk mewujudkan otonomi daerah. Jangan sampai justru luasnya penerapan disentralisasi berdampak buruk pada eksistensi negara kesatuan Indonesia.

\section{Implikasi Pemekaran Daerah di Kabupaten Pesawaran Provinsi Lampung}

Desentralisasi dalam arti pemencaran kekuasaan dapat dilakukan secara teritorial melalui pembentukan daerah-daerah otonom. Desentralisasi teritorial ini dilakukan sebagai upaya untuk mendekatkan jarak antara pemerintah dengan yang diperintah. Pemerintahan di tingkat lokal diperlukan untuk efisiensi dan efektivitas dalam hal keuangan, penegakan hukum, administratif, pelayanan publik dasar, dan urusan-urusan lain yang akan sulit dilakukan hanya oleh pemerintah pusat. Karena itu, pemencaran kekuasaan secara teritorial juga akan berkaitan dengan penentuan fungsi dan kewenangan apa yang paling tepat untuk dilaksanakan oleh level nasional, level propinsi, ataupun level kota/kabupaten. Dengan kata lain, desentralisasi teritorial akan diikuti oleh desentralisasi kewenangan. Hal ini akan menentukan jumlah urusan yang dilaksanakan oleh daerah otonom tersebut.

Dalam konsep negara kesatuan seperti yang diterapkan di Indonesia, desentralisasi teritorial tidak menyebabkan terjadinya pengurangan wilayah negara meskipun terjadi pemekaran, penggabungan ataupun penghapusan daerah otonom. Daerahdaerah otonom yang berupa Kabupaten/Kota tetap menjadi bagian dari wilayah Provinsi, dan wilayah-wilayah Provinsi tetap menjadi 
wilayah dari negara. Yang berbeda antara negara (pusat), provinsi, kabupaten/kota bahkan desa hanyalah kewenangan atau otoritasnya yang tercermin dari urusan dan fungsi yang menjadi kewenangannya.

Pada dasarnya, setiap pemerintah daerah di tingkat provinsi maupun kabupaten/kota memiliki infratsruktur dan struktur pemerintahan yang relatif standar. Infrastruktur tersebut meliputi gedung, fasilitas, sarana dan prasarana. Sedangkan struktur pemerintahan terdiri atas pimpinan serta anggota dewan legislatif daerah, seorang pimpinan dan wakil pimpinan daerah, sekretariat daerah sebagai pusat kegiatan administrasi daerah, serta sejumlah dinas, badan dan kantor yang mengelola kegiatan pembangunan untuk masing-masing sektor di daerah. Namun, bila suatu daerah dimekarkan dan terbentuklah daerah otonom baru, maka dibutuhkanlah infrastruktur, sarana dan prasarana yang banyak, kelembagaan baru, dinas-dinas, dan sejumlah posisi-posisi baru untuk ditempati. Seiring dengan pemenuhan struktur dan infrastruktur tersebut, maka sebuah daerah yang akan dibentuk jika tidak memiliki persiapan yang matang tentu akan mengalami kesulitan dalam menentukan anggaran belanja daerah tersebut. Sementara dana transfer dari pusat hanya difokuskan pada belanja rutin dalam bentuk gaji pegawai serta tunjangan lainnya, karena secara riil pendapatan daerah masih rendah, maupun dalam bentuk belanja modal untuk mendukung kegiatan masing-masing instansi tersebut seperti belanja modal untuk gedung tempat kerja, peralatan kerja serta infrastruktur lainnya, termasuk kendaraan dinas.

Kondisi ini berkorelasi dengan studi yang dilakukan oleh Ratnawati, LIPI, USAID, dari kurun 2005-2008 bahwa peningkatan jumlah kabupaten dalam suatu provinsi telah meningkatan share pengeluaran pemerintah daerah, utamanya belanja daerah didominasi oleh belanja rutin. ${ }^{38}$ Demikian halnya, dalam konteks

${ }^{38}$ Studi Evaluasi atas problematika pemekaran telah banyak dilakukan oleh peneliti asing maupun dalam negeri,semisal USAID, LIPI, Kompas,dll. Lihat Tim Percik, Proses dan Impikasi..., I0. 
Pesawaran. Alokasi belanja daerah, lebih dari setengahnya (sekitar 88 persen) dialokasikan untuk gedung, peralatan dan kendaraan bermotor, gaji pegawai, dll. Dan untuk alokasi pelayanan publik sangat minim sekali, yakni hanya sekitar 12 persen. ${ }^{39}$

Terlepas dari realitas itu, setiap kebijakan hukum, pasti memiliki implikasi secara positif maupun negatif. Tidak terkecuali dengan pembentukan Pesawaran. Implikasi positif yang paling nyata dalam wilayah administratif pasca pembentukan Pesawaran di antaranya: Pertama, rentang kendali pemerintahan semakin dekat; Kedua, terbukanya jabatan-jabatan (peluang kerja) baru untuk sebagian kecil masyarakat asli dan sekitar, terutama dalam sektor pemerintahan kabupaten; Ketiga, akses pelayanan publik semakin dekat; Keempat, adanya distribusi fiskal ke daerah otonom baru sebagai upaya pembangunan dan penunjang struktur dan infrastruktur baru.

Sedangkan Implikasi negatif yang paling nyata adalah: Pertama, terkait persoalan lokasi kompleks kantor pemerintahan Kabupaten Pesawaran. Jika merujuk pada proposal Pembentukan Kabupaten Pesawaran yang diusulkan P3KP serta Pemda Lampung Selatan kepada pemerintah pusat, lokasinya adalah tanah seluas 60 hektare milik PT. Pluit Makmur Lestari (PML) yang katanya sudah dibeli. Namun dalam perkembangannya, justru lahan tersebut oleh pihak pemilik diperpanjang Hak Guna Usahanya (HGU) hingga 30 tahun dan belum ada kesepakatan dengan pemerintah kabupaten. ${ }^{40}$ Artinya, lokasi kompleks perkantoran yang tercantum dalam usulan pembentukan Pesawaran tersebut cacat secara administratif dan merupakan hasil negosiasi politik. Padahal dalam PP nomor 129 Tahun 2000 bahwa lokasi calon kompleks perkantoran kabupaten harus sudah ditentukan dan dimiliki secara sah. Terkait persoalan tersebut maka tidak heran, jika kemudian lokasinya saat ini berpindah di sebidang tanah seluas 40 hektare di desa Way Layap yang dibeli justru pasca dasar Kabupaten Pesawaran

39 Syafarudiin, Wawancara, Lampung, I5 Juni 201 I.

40 Maulana Mukhlis, “Pencederaan Pemekaran Pesawaran,” dalam Lampung Post edisi 21 April 2008. 
diresmikan. Persoalan tidak sampai di situ, karena keterlambatan dana hibah dari provinsi maupun daerah induk maka, rencana pembangunan gedung kantor bupati dan DPRD baru disusun tahun 2009 yang kemudian baru terealisasi di tahun 2010 untuk pembangunan kantor Bupati. ${ }^{41}$

Kedua, implikasi yang juga timbul dari pemekaran Pesawaran adalah keterbatasan infrastruktur dan struktur penyelenggara pemerintahan, semisal DPRD, dinas-dinas, Bapeda, dll. Tentang hal ini, ketua Harian Trans Lampung, Matrohupi menyatakan: ${ }^{42}$

Kantor DPRD sebenarnya merupakan pindahan, gedung itu yang digunakan sekarang masih menumpang kantor kecamatan Gedong Tataan. Sedangkan kantor kecamatan Gedongtataan dipindahkan ke kantor kelurahan terdekat. Kemudian kantor bupati disampinya itu merupakan rumah penduduk yang dibeli dan direnovasi menjadi kantor bupati. Akibatnya yang pelayanan yang diberikan ya alakadarnya, karna fasilitasnya juga seperti itu. Selain itu, semua dinas dan lembaga kelengkapan kabupaten juga masih mengontrak di rumah-rumah warga di sekitar Gedong Tataan, dan itu bahkan mencar-mencar dan ada yang masuk didalam kampung, ya karena dapatnya di rumah pedalaman. Yang tejadi bisa dilihat sendiri, dinas-dinas tersebut tidak bisa memberikan pelayanan maksimal, para tamu dan masyarakat yang datang membutuhkan pelayanan, harus berbesar hati karena ruangannya sangat sempit, harus berbagi tempat dengan para pegawai yang lalu lalang. Untuk menampung pegawai saja sudah

\footnotetext{
41 Maulana Mukhlis, Wawancara, Lampung, 30 Januari 2011.

42 Matrohupi, Wawancara, Lampung, 2 I Juni 20 I I. Kabupaten Pesawaran sebagai kabupaten yang baru terbentuk sejak awal dirundung masalah. Karena selain Kabupaten Pesawaran termasuk daerah miskin sumber daya alam juga lahir karena mobilisasi elite politik lokal. Sehingga ketika ada masalah kecil, langsung diangkat ke permukaan oleh penggiat LSM dan orang-orang yang berjasa atas terbentuknya kabupaten baru ini. Masyarakat Pesawaran sesungguhnya jengah dengan kondisi itu. Termasuk persoalan lokasi kantor pemerintahan yang bermasalah. Kantor bupati hingga kini masih menumpang di bekas kantor camat Gedung Tataan. Kantor dinas menyewa rumah-rumah penduduk di sekitar Desa Bagelen dan Sukaraja. Ironisnya, pembangunan di kabupaten ini masih mengandalkan bantuan pemerintah provinsi dan kabupaten induk. Akibatnya banyak proyek pembangunan terbengkalai. Selain itu, pelaksanaan pembangunan penuh curiga dan amarah dari oknum-oknum LSM dan ormas. Lihat "Pemekaran Dipaksakan Pesawaran Melarat," dalam Rakyat Merdeka edisi 24 Mei 2010.
} 
penuh sesak apalagi untuk tamu, ya itu karenatidak sesuai dengan kapasitas rumah.....

Argumentasi lain juga dapat dicermati dari pernyataan Maulana Mukhlis, seorang tokoh sosial politik Lampung, berikut: ${ }^{43}$ ...ketika Pesawaran mekar, banyak janji Pemprov Lampung dan Pemda Lamsel untuk memberikan support anggaran tidak diberikan sehingga perjalanan awal kabupaten ini terseok-seok. Kemudian janji masyarakat untuk menghibahkan lahan perkantoran tercederai sehingga alokasi dana pembangunan yang sebenarnya dapat dimanfaatkan untuk publik justru dipakai untuk pembelian lahan. Selain itu, banyak data dukung yang tercantum dalam naskah usulan tentang potensi Pesawaran ternyata tidak secara nyata ada sehingga keterbatasan pendapatan daerah belum dapat disuplai dengan potensi yang ada. Akibatnya PAD sangat kecil dan ketergantungan kepada pemerintah pusat sangat tinggi.

Selain itu, ketidaksiapan pemerintahan juga tampak timbul dalam ranah pengurusan dokumen kependudukan, semisal kependudukan, catatan sipil dan SIM, karena keterbatasan sarana di Pesawaran, proses pengurusannya pun masih terintegrasi di daerah Induk, yakni Lampung Selatan. ${ }^{44}$

Ketiga, keterbatasan anggaran. Kondisi paling mengemuka berdampak pada keterlambatan proses pemilukada. Dengan anggaran daerah yang minim sementara belanja rutin daerah begitu tinggi, sehingga berdampak pada keterbatasan anggaran agendaagenda besar semisal pemilukada. Sehingga pemilukada yang seharusnya sudah harus dilakukan ditahun 2008 menjadi molor hingga tahun 2010 untuk menunggu kesiapan dana tersebut. Padahal secara tegas Undang-Undang Nomor 32 Tahun 2004 menyatakan bahwa $\mathrm{Pj}$. Bupati ditunjuk maksimal dua tahun pasca daerah otonom terbentuk. Namun, dalam konteks Pesawaran realiasi amanat Undang-Undang tersebut tidak dapat dilaksanakan secara baik, apalagi dengan masih runyamnya penataan daerah

${ }^{43}$ Maulana Mukhlis, Wawancara, Lampung, 30 Januari 2011.

${ }^{44}$ Observasi di Pesawaran pada 27 Juni 201 I . 
awal pemekaran, institusi penyelenggara pemilukada juga belum terbentuk. ${ }^{45}$

Persoalan yang paling mengemuka dari silang sengkarut pemilukada Pesawaran pada saat itu adalah jadwal Pemungutan dan Penghitungan Suara yang sering berubah. Hal ini terihat dari agenda pemilukada pertama Pesawaran yang seharusnya dilaksanakan pada tanggal 29 Maret dirubah menjadi tanggal 30 Juni 2010. Hal ini telah melanggar asas 'kepastian hukum' sebagaimana diatur dalam Pasal 2 Undang-Undang Nomor 22 Tahun 2007 tentang Penyelenggara Pemilu jo Pasal 2 Peraturan KPU nomor 68 tahun 2009, Tentang Pedoman Teknis Tata Cara Pencalonan Pemilihan Umum Kepala Daerah dan Wakil Kepala Daerah. Hal ini dapat dicermati Keputusan KPU No : 01 Tahun 2009 Tentang Tahapan, Program, dan Jadwal Penyelengggaraan Pemilihan Umum Kepala Daerah dan Wakil Kepala Daerah Kabupaten Pesawaran Tahun 2010. Dalam lampiran keputusan tersebut tersebut dinyatakan bahwa "Pelaksanaan Pemungutan Suara dan Penghitungan Suara di TPS oleh KPPS, dilaksanakan pada tanggal 29 Maret 2010", akan tetapi pada tanggal 13 Februari 2010 tepatnya satu bulan setengah sebelum hari Pencoblosan dirubah dengan Keputusan nomor 270/39/KPUPSW/ II/2010 yang pada intinya menunda pelaksanaan Pemungutan Suara dan Penghitungan Suara di TPS oleh KPPS. ${ }^{46}$

Kondisi dilematis Pesawaran juga dapat dicermati dari pernyataan Khairudin Tahmid, berikut: ${ }^{47}$

“...penataan daerah pasca pemekaran Pesawaran merupakan persoalan yang kompleks. Selain karena kesiapan daerah yang mekar kurang, juga provinsi maupun daerah induk dalam melakukan pembinanan juga setengah hati. Apalagi intrik perebutan kekuasan juga terjadi. Hingga lahirnya qabîlah-qabîlah/ trah-trah kesukuan dalam daerah DOB, semisal trah Ratu Atut di

\footnotetext{
45 Maulana Mukhlis, “Pencederaan Pemekaran Pesawaran," dalam Lampung Post edisi 2 I April 2008.

46 Putusan Mahkamah Konstitusi No. 109 \& I I O/PHPU.D-VIII/20 I 0 tentang Sengketa Pemilukada Pesawaran Tahun 2010.

${ }^{47}$ Khairudin Tahmid, Wawancara, Lampung, 18 Juni 2011 .
} 
Banten, dan Trah Syahrudin di Lampung Selatan, trah Sarbini di Pesawaran dan Menggala. Ini menunjukkan bahwa pemekaran bukan kehendak warga tetapi elite yang berkepentingan dengan menjadikan masyarakat sebagai objek sekaligus subjek.

Dari pernyataan itu dapat diketahui bahwa daerah hasil pemekaran memang menyimpan amunisi politik dan sarat kepentingan. Terlebih DOB merupakan tempat arena perebutan jabatan-jabatan baru da proyek-proyek baru. Dibutuhkan kesungguhan dari banyak pihak, utamanya pemerintah pusat agar makna desentralisasi tidak sebatas pada pembentukan pemerintahan otonom baru tapi sebagai efektifitas penyelenggaraan pemerintahan pada tingkat daerah dalam mewujudkan kesejahteraan rakyat.

Selain keterlambatan pemilukada, keterbatasan dana juga berimplikasi pada lahirnya kebijakan-kebijakan formalitas belaka dan tidak kreatif. Kondisi keterbatasan dan kondisi infrastruktur yang belum memadai dianggap sebagai latar belakang yang menyulitkan, sehingga berimplikasi kepada prioritas kebijakan yang tidak populer. Hal ini misalnya dapat dicermati dari pernyataan Sekretaris Dinas Pendidikan Kabupaten Pesawaran tentang pemotongan anggaran yang harus dikalahkan secara drastis oleh kebutuhan anggaran lainnya, berikut ini.

Sudah dianggarkan 20 milyar rupiah untuk Dinas Pendidikan, menjelang pilkada dipotong dari 20 milyar tinggal 8 milyar. Jika DAK dari pusat tidak masalah, Cuma yang menjadi masalah itu anggaran yang dari APBD, karena ada pemilihan bupati. Jadi kebijakan politik itu yang harus didahulukan, kalo untuk masyarakat nanti dulu.

Dari pernyataan tersebut dapat dicermati bahwa ada suasana ironis terhadap kebutuhan dalam sektor pendidikan yang dikalahkan oleh kebutuhan pemilihan kepala daerah. Suasana ironis tersebut lebih dikarenakan drastisnya penurunan anggaran pada sektor pendidikan, seolah tidak terdapat sumber lain yang bisa menutupi persoalan anggaran politik tersebut. Dari cara pengelolaan anggaran ini saja bisa dipahami adanya keterbatasan 
anggaran dan kreativitas penggalian anggaran, sehingga harus memangkas jumlah yang sangat besar dalam sektor pendidikan. Pada rentang yang selanjutnya persoalan keterbatasan anggaran dan berbagai sumber daya lainnya tersebut selanjutnya mengakibatkan tidak berkembangnya kreatifivitas dalam kebijakan pada tingkat pembangunan daerah. Kondisi minimnya ruang bagi kreativitas dalam menjalankan pemerintahan tersebut membentuk pola yang sirkuler dan berlanjut pada aktivitas teknis masingmasing instansi. Misalnya, lumpuhnya aktivitas DPRD Pesawaran akibat dana kegiatan rutin triwulan ketiga wakil rakyat tersebut tak bisa dicairkan. Selain itu, honorarium puluhan staf tenaga honorer di DPRD Pesawaran sejak tiga bulan, terhitung April, Mei, Juni tak bisa dibayarkan. Banyak yang menduga laporan pertanggungjawaban penggunaan anggaran DPRD Pesawaran untuk triwulan pertama dan kedua bermasalah, sehingga Bagian Keuangan Pemkab Pesawaran tidak mencairkan dana kegiatan rutin triwulan ketiga DPRD Pesawaran. Ketua Badan Kehormatan (BK) DPRD Pesawaran Rama Diansyah bahkan menuntut Sekretariat DPRD Pesawaran harus mempertanggungjawabkan kegiatan para anggota DPRD Pesawaran yang tak bisa berjalan karena dana kegiatan rutin triwulan ketiga tidak ada. ${ }^{48}$

Tentu, persoalan menjadi semakin nyata, ketika Kepala Inspektorat Kabupaten Pesawaran Hendarma, menyebut bahwa terdapat 55 kasus pelanggaran yang dilakukan aparatur pemerintah sejak Januari-Desember 2011. Dugaan penyimpangan anggaran, dan penyalahgunaan wewenang menjadi kasus yang paling dominan ditangani Inspektorat. Selain penyimpangan anggaran, dan penyalahgunaan wewenang, Inspektorat juga mencatat temuan seperti penyimpangan proyek pembangunan dan tindakan indisipliner aparatur pemerintah. Dibandingkan tahun 2010, pada 2011 terjadi peningkatan jumlah kasus, yakni sebanyak 48 kasus.

48 "DPRD Pesawaran Keluhkan Keuangan," dalam Lampung Post Edisi I 4 Juli 201 I. 
Kondisi ini tidak lain karena lemahnya pengawasan dari aparat yang bertanggung jawab. ${ }^{49}$

Dalam sektor pelayanan publik dasar, semisal pendidikan, karena alasan anggaran minim tidak terdapat peningkatan kualitas pendidikan dan peningkatan perhatian pemerintah dalam sektor pembangunan sarana pendidikan setelah di mekarkan. Bahkan banyak warga yang justru merasa lebih baik ketika belum mekar dari Lampung Selatan. ${ }^{50}$ Artinya, dengan beragamnya persoalan keadmisnistrasian tersebut mencerminkan masih belum matangnya kapasitas dan kapabilitas penyelenggara kebijakan di Kabupaten Pesawaran.

Kelima, Implikasi lain yang juga timbul adalah terkait hubungan kerja antara Kabupaten Pesawaran dengan Pemerintah Provinsi. Permasalahan yang terjadi dalam konteks hubungan kerja tersebut berkaitan dengan perbedaan yang terjadi antara struktur organisasi dan tugas pokok serta fungsi dari satuan kerja perangkat daerah (SKPD) yang terdapat di masing-masing pemerintahan. Misalnya dalam konteks Dinas Pendidikan. Dinas Pendidikan Kabupaten Pesawaran seringkali menghadapi masalah dalam hal rumusan tugas pokok dan fungsi dari unit-unit kerja pada instansi yang membawahi kewenangan pendidikan. Penggunaan Peraturan Pemerintah No 41 Tahun 2007 oleh Kabupaten Pesawaran sudah merinci pembagian tugas dan fungsi yang berada di bawah Dinas Pendidikan tersebut, namun pihak Dinas Pendidikan Provinsi Lampung yang ternyata tidak menerapkan Peraturan Pemerintah Nomor 41 Tahun 2007 memiliki rumusan tugas dan fungsi masingmasing unit yang berbeda.

\footnotetext{
49 "Penyimpangan Anggaran Dominan di Pesawaran," dalam Lampung Post Edisi Rabu, 14 Desember 2011 .

$50 \mathrm{Hal}$ ini misalnya bisa dicermati pada saat terjadinya musibah runtuhnya tembok sebuah sekolah, yaitu SDN 3 Karanganyar hingga mengakibatkan korban jiwa. Diketahui bahwa pihak SDN 3 Karanganyar sebenarnya sudah jenuh mengajukan proposal perbaikan bangunan sekolah kepada Dinas Pendidikan. Tetapi, ketika ditanya mengapa bangunan SDN 3 Karanganyar yang sudah 26 tahun dan tidak pernah sekali pun mendapat dana perbaikan, Kepala Dinas Pendidikan, M. Izhar enggan menjawab. Lihat Lampung Post, Edisi Sabtu, I 5 Agustus 2009.
} 
Perbedaan yang terjadi dalam rumusan tugas dan fungsi unit kerja tersebut yang kemudian menyebabkan terjadinya beberapa permasalahan koordinasi dan persepsi di antara kedua Dinas Pendidikan tersebut. Seringkali dihadapkan kepada perdebatan ketika suatu kebijakan dari Pemerintah Provinsi kepada Kabupaten Pesawaran atau kebijakan Pemerintah Pusat yang diturunkan kepada Pemerintah Kabupaten Pesawaran melalui Pemerintah Provinsi Lampung. Perdebatan itu terjadi karena perbedaan ruang lingkup yang terjadi antara Dinas Pendidikan dari masing-masing pemerintahan. Oleh karena itu, Pimpinan dari Dinas Pendidikan Kabupaten Pesawaran kemudian mengatasi persoalan ruang lingkup kerja tersebut melalui pendekatan musyawarah dinas yang berisikan pembagian dan pemerataan kerja pada seluruh unit kerja di lingkungan Dinas Pendidikan Kabupaten Pesawaran, unit kerja ini diantaranya adalah Bidang-bidang, Sub Bidang dan Seksi yang memiliki rincian tugas dan fungsi masing-masing. Persoalan ini juga hampir dialami oleh semua dinas yang ada di Pesawaran, selain keterbatasan infrastruktur dan SDM yang juga sangat dirasakan dampaknya.

\section{Penutup}

Terbentuknya Kabupaten Pesawaran berdasarkan UndangUndang Nomor 33 Tahun 2007. Kemudian sebagai tindak lanjut penetapan Undang-Undang Nomor 33 Tahun 2007, Menteri Dalam Negeri menerbitkan Pedoman Pelaksanaan Undang-Undang tentang Pembentukan Kabupaten/Kota melalui Surat Menteri Dalam Negeri Nomor. 135/2051/SJ tanggal 31 Agustus 2007 dan pada tanggal 2 November 2007 Menteri Dalam Negeri atas nama Presiden Republik Indonesia, melaksanakan peresmian pembentukan Kabupaten Pesawaran dengan melantik Drs. H. Haris Fadilah, M.M sebagai Pejabat Bupati Pesawaran yang pertama dan dilanjutkan dengan penandatanganan prasasti oleh Menteri Dalam Negeri atas nama Presiden Republik Indonesia.

Implikasi positif yang paling nyata dalam wilayah administratif pasca pembentukan Pesawaran di antaranya: Pertama, 
rentang kendali pemerintahan semakin dekat; Kedua, terbukanya jabatan-jabatan (peluang kerja) baru untuk sebagian kecil masyarakat asli dan sekitar, terutama dalam sektor pemerintahan kabupaten; Ketiga, akses pelayanan publik semakin dekat; Keempat, adanya distribusi fiskal ke daerah otonom baru sebagai upaya pembangunan dan penunjang struktur dan infrastruktur baru.

Implikasi administratif negatif yang timbul dari pembentukan Kabupaten Pesawaran meliputi silang sengkarut lokasi kantor pemerintah kabupaten, keterbatasan anggaran akibat tidak kreatifnya kepala daerah dalam menggali pendapatan sehingga terbengkalainya pemilukada perdana, keterbatasan infrastruktur, pelayanan publik yang semakin buruk, dan hubungan kerja yang kurang harmonis antar pimpinan dan pejabat daerah.

\section{Daftar Pustaka}

Daniel, Laurensius. "Problem Pemekaran Daerah dan Prospek Otonomi Daerah". www.equator-news.com. diakses pada 15 Januari 2016.

Djojosoekarto, Agung, dkk. Grand Strategy Penataan Daerah Tahun 2025. Jakarta: Kemitraan, 2008.

DPRD Pesawaran Keluhkan Keuangan. Lampung Post. Edisi 14 Juli 2011.

Fahmi, Sudi. Hukum Otonomi Daerah. Yogyakarta: Total Media, 2010. Fauzi, Gamawan. "Paradigma Kewenangan Daerah yang Efektif dan Efisien". Majalah Prisma. Volume 29/No 3/Tahun 2010.

Gadjong, Agussalim Andi. Pemerintahan Daerah dalam Kajian Politik dan Hukum. Bogor: Ghalia Indonesia, 2007.

Gie, The Liang. Pertumbuhan Pemerintahan Daerah di Negara Republik Indonesia (1). Jakarta: Gunung Agung, 1967.

Hidayat, Syarif. Refleksi Realitas Otonomi Daerah dan Tantangan ke Depan. Jakarta: Pustaka Quantum, 2000.

Huda, Ni'matul. Hukum Pemerintahan Daerah. Jakarta: Penerbit Nusamedia, 2009. 
Jeddawi, Murtir. Pro-Kontra Pemekaran Wilayah; Analisis Emperis. Yogyakarta: Total Media, 2009.

Kompas. Edisi 11 Februari 2008.

Kusuma, R. M. A. B. Lahirnya Undang-Undang Dasar 1945. Jakarta:

Pusat Studi Hukum Tata Negara Fakultas Hukum

Universitas Indonesia, 2004.

Lampung Post. Edisi Sabtu, 15 Agustus 2009.

Lay, Cornelis dan Purwo Santoso. Perjuangan Menuju Puncak; Kajian Akademik Pembentukan Kabupaten Puncak Jaya Papua. Yogyakarta: Kerjasama PLOD UGM dan Pemerintah Papua, 2006.

Marbun, B.N. Kamus Politik. Jakarta: Pustaka Sinar Harapan, 2007.

Marta, M Fajar dan Yulvianus Harjono. “Otonomi Daerah Lampung (6), Pemekaran Masihkah Perlu?". Kompas. Edisi Selasa, 2 November 2010.

Marzuki, M. Laica. "Hukum dan Pembangunan Daerah Otonom". Kertas Kerja PSKMP-LPPM UNHAS Makassar 18 Nopember 1999.

Matutu, Mustamin DG. dkk. Mandat, Delegasi, Attribusi dan Implementasinya di Indonesia. Yogyakarta: UII Press, 1999.

Mukhlis, Maulana. "Pencederaan Pemekaran Pesawaran". Lampung Post. Edisi 21 April 2008.

Nasution, Ajarotni (ed.). Naskah Akademik tentang Penghapusan dan Penggabungan Daerah. Jakarta: BPHN, Depkumham, 2008.

Nazara, Suahazil dan Nurkholis. "Evaluasi Pemekaran Wilayah kabupaten/ Kota di Indonesia dalam Era Desentralisasi". Jurnal Ekonomi. Volume 5, No 2, 2006.

Noer, Deliar. Pengantar ke Pemikiran Politik. Jakarta: CV. Rajawali, 1983.

Nordholt, Henk Schulte dan Gerry Van Klinken (ed.). Politik Lokal di Indonesia. Jakarta: Yayasan Obor Indonesia-KITLV, 2007.

Pemekaran Dipaksakan Pesawaran Melarat. Rakyat Merdeka. Edisi 24 Mei 2010. 
Penyimpangan Anggaran Dominan di Pesawaran. Lampung Post. Edisi Rabu, 14 Desember 2011.

Putri, Vera Jasini. Kamus Hukum dan Glosarium Otonomi Daerah. Jakarta: YPBHI, 2003.

Putusan Mahkamah Konstitusi Nomor 109 \& 110/PHPU.DVIII/2010 tentang Sengketa Pemilukada Pesawaran Tahun 2010.

Ratnawati, Tri. Pemekaran Daerah; Politik Lokal dan Beberapa Isu Terseleksi. Yogyakarta: Pustaka Pelajar, 2009.

Santoso, Lukman. "Problematika Pemekaran Daerah Pasca Reformasi di Indonesia". Supremasi Hukum. Vol. 1, Nomor 2, Desember 2012.

Saury (As-), Rahmatul Ummah. "Memperkuat Demokrasi Lokal". http://politik.kompasiana.com/2010/11/04/memperkuatdemokrasi-lokal/, diakses tanggal 15 Februari 2016.

Sejarah Terbentuknya Kabupaten Pesawaran dalam http:// pesawarankab.go.id/, akses 15 Januari 2016.

Sunarno, Siswanto. Hukum Pemerintahan Daerah di Indonesia. Jakarta: Penerbit Sinar Grafika, 2009.

Tarigan, Antonius. "Dampak Pemekaran Wilayah". Majalah Perencanaan. Edisi 01/ tahun XVI/2010.

Taryono. "Dilema Demokrasi dan Otonomi Daerah". Tribun Lampung. Edisi 25 Maret 2010.

Tim Lapera. Otonomi Versus Negara; Demokrasi di Bawah BayangBayang Otoriterisme. Yogyakarta: Lapera Pustaka Utama, 2005.

Tim Percik. Proses dan Implikasi Sosial-Politik Pemekaran; Studi Kasus di Sambas dan Buton. Salatiga: Yayasan Percik, 2007.

Wignjosoebroto, Soetandyo. "Satu Abad Desentralisasi di Indonesia". Majalah Prisma No 3, Vol 29/ Juli 2010. 